\title{
İletişimsel Edinç ve Alıştırma Türleri: Almanca Dersine Yönelik Bir Durum Çalış̧ması
}

\author{
Handan Köksal (iD, Edirne - Eşe Büşra Akın (i), Elazı̆̆ \\ https://dx.doi.org/10.37583/diyalog.958497
}

$\ddot{O} z$

Bu çalışmanın amacı 'Plus+ Deutsch A1.1' Almanca ders kitabındaki alıştırma türlerinin derslerde uygulanma durumunun belirlenmesi ve uygulanan alıştırma türlerinin iletişimsel edinç geliştirme bağlamında durum çalışması deseni ile değerlendirilmesidir. Araştırmanın çalışma grubunu 2019-2020 Eğitim-Öğretim yılı üç farklı lisede görev yapan Almanca öğretmenleri $(n=3)$ ile bu okullarda öğrenim gören 9. ve 10. sınıf öğrencileri oluşturmaktadır $(\mathrm{n}=194)$. Çalışmada veriler doküman, anket ve görüşme gibi veri toplama teknikleri kullanılarak değerlendirilmiştir. Araştırmada 'Plus+ Deutsch A1.1' 'in öğrencilerin bilişsel ve iletişimsel gelişimini destekleyen alıştırma türlerini içerdiği tespit edilmiştir.

Anahtar Sözcükler: Illetişimsel Edinç, Alıştırma Türleri, Almanca Eğitimi, Durum Çalışması, Plus + Deutsch A1.1.

\section{Abstract}

\section{Communicative Competence and Exercise Types: A Case Study for German Lessons}

The purpose of this study is to determine the application status of the exercise types in the 'Plus + Deutsch A1.1' German textbook in the lessons and to evaluate the applied exercise types in the context of communicative competence according to the case study method. The study group consists of German teachers $(n=3)$ working in three different high schools in the 2019-2020 Academic Year and $9^{\text {th }}$ and $10^{\text {th }}$ grade students $(n=194)$ of these schools. In the study, the data were analysed using document analysis, questionnaire and interview. In the research, it was determined that 'Plus+ Deutsch A1.1' contains the types of exercises that support students' cognitive and communicative competence.

Keywords: Communicative Competence, Exercise Types, German Education, Case Study, Plus + Deutsch A1.1.

Einsendedatum: 08.01.2021 


\section{EXTENDED ABSTRACT}

Social, economic, political and cultural developments in the globalising world also affect the field of education. In accordance with the age, as a second language teaching program Secondary School German Curriculum has been renewed according to the constructivism approach by the Ministry of Education in Turkey since 2005. The aim of the Secondary School German Curriculum is to develop the students' German language proficiency in line with the four basic skills (reading, speaking, listening and writing) and to provide students with the communicative competence that they will shape according to the individual needs of the students. This view is also supported by the communicative approach. In this context, communicative competence, which contributes to students' behaviour through a foreign language, comes to the fore in foreign language lessons. Besides, it is emphasised in the Secondary School German Curriculum that the exercises should be arranged by the level of language learners, be meaningful and encourage the learner's cognitive skills. It is thought that the types of exercises and their application in the textbook, which is the main resource in the lessons, mediate the fulfilment of social, communicative and cognitive conditions in the lessons. A study examining the types of exercises in the context of communicative competence development in German teaching was not found in the literature. This study possesses an originality value both in terms of filling this gap in the literature and being an in-depth study of the types of exercises. This study aims to determine the application status of the exercise types in the "Plus+ Deutsch A1.1" German textbook in the lessons and to evaluate the applied exercise types in the context of communicative gain.

The research was designed according to the case study method. The study group of the research consists of German textbook "Plus+ Deutsch A1.1", 2019-2020 Academic Year Spring Semester Izzettin Çalışlar Anatolian High School, Vala Gedik Anatolian High School and Ahmet Avc1 Anatolian High School and the 9th and 10thgrade students studying in these schools. In the study, the data were analysed using three different data collection techniques: document analysis, questionnaire and interview. "Plus+ Deutsch A1.1" German student textbook, which was taught in the $9^{\text {th }}$ and $10^{\text {th }}$ grades of Secondary Education in the fall and spring semesters of 2019-2020 academic year, was used as the first data collection tool. As for the following data collection tool, a questionnaire was conducted to students. The next data tool was "German Lesson Teacher Opinion Form" and "German Lesson Student Interview Form" used in individual interviews with teachers and students. Face to face interviews could not be conducted with all the students participating in the study due to the pandemic. Hence, individual interviews were conducted with the students who were chosen based on the appropriate sampling approach, which is one of the non-random sampling methods. In this case, one-on-one interviews were conducted sequentially with six students who participated in the study and were selected based on the appropriate sampling approach. In the analysis of individual interviews, content analysis method was used.

The types of exercises in the textbook subject to the research were examined based on the renewed cognitive process steps of Bloom's taxonomy in cognitive sense 
and the types of exercises determined by Funk et al. (2014) in terms of communication. In the research, it was determined that the German textbook "Plus + Deutsch A1.1" contains the types of exercises that support students' cognitive and communicative development. According to the results of the research, the activities carried out "in groups of only three or more people" in the textbook subject to the research are conducted seldom in the lessons. It is thought that the types of exercises in the textbook subject to the inquiry and their application in the courses contribute to the students' acquiring communicative competence. 


\section{Giriş}

$\mathrm{Bu}$ bölümde yapılandırmacı yaklaşım (Konstruktivismus), iletişimsel edinç (Kommunikative Kompetenz), sosyal formlar (Sozialformen) olarak alıştırmalar (Übungen), görevler (Aufgaben), etkileşimler (Interaktionen) konu edilecek ve kavramlar alıştırma türleri (Aufgabentypen) açısından değerlendirilecektir.

Küreselleşen dünya ile birlikte ekonomik, siyasal, toplumsal ve kültürel alanlarda gelişmeler yaşanmaktadır. Eğitim alanına da yansıyan bu gelişmeler doğrultusunda Millî Eğitim Bakanlığı (MEB) tarafından eğitimde bazı değişiklikler yapılmaktadır. Açıkgenç vd. (2011) bu değişikler kapsamında yeni öğretim programları 2005-2006 yılından beri yapılandırmacı yaklaşımına dayandığını vurgulamaktadır. Yapılandırmacılık öğrenenlerin kendi deneyimleriyle bir anlam oluşturduğu bir öğrenme kuramıdır. Buna göre anlamlandırma ve deneyim arasında sıkı bir ilişki bulunmaktadır. Birey, yeni bilgiler ile var olan bilgilerini ilişkilendirir. Bireyin bilişsel yapısını yeniden düzenlemesi için bir koşul olan bu ilişkilendirmeyi birey, kendi zihinsel çerçevesine uygun olarak yapılandırır (bkz. Arslan 2007: 46). Eğitimde bilgi aktarımından ziyade kişiye bilgiyi edinme yollarının öğretilmesi için zengin ortamlar sağlanması gerekmektedir. Kişinin yaşamda devamlı problemlerle karşılaşması ve bunları çözmeye çalışması aynı zamanda bir yaşantı geçirmesi demektir. Yapılandırmacı yaklaşıma göre öğrencilerden yerine getirmeleri beklenen öğrenme görevlerinin öğrenme içeriklerinin gerçek yaşamdakine benzer şekilde karmaşık ve detaylı olması gerekmektedir. Bu sayede öğrenciler derslerdeki gerçek yaşamda yer alan öğrenme bilgilerini ve yaşantılarını ileride karşılaştığı benzer ve yeni durumlara kolay bir şekilde transfer edebilir (bkz. Sönmez 2017; bkz. Er ve Aral 2008).

Eğitim alanındaki bu gelişmeler doğal olarak yabancı dil olarak Almanca öğretimini de etkilemektedir. Ortaöğretim Almanca Dersi Öğretim Programı'nın (2018) amacı öğrencilerin Almanca dil yeterliliklerinin dört temel beceri (okuma, konuşma, dinleme, yazma) doğrultusunda geliştirilmesi ve yaşam boyu öğrencilerin bireysel ihtiyaçlarına göre şekillendireceği iletişim edincinin öğrencilere kazandırılmasıdır. Ortaöğretim Almanca müfredatı hazırlanırken öğrencilerin yabancı dil derslerinde dili kullanmaları, dilin kurallarını yani hangi cümle yapılarını ne zaman kullanmaları ya da kullanabilmeleri gerektiğini bilmeleri, hem işbirlikçi hem de bağımsız olarak yabancı dil öğrenme süreçlerini şekillendirmeleri ve değerlendirmeleri dikkate alınmıştır. Bu görüş iletişimsel yaklaşım tarafından desteklenmektedir (Baliuk vd. 2018; Ortaöğretim Almanca Dersi Öğretim Programı 2018).

İletişimsel yaklaşıma göre en önemli kavram iletişimdir ve dil bir iletişim aracıdır (Güneş 2011: 134). Dilsel eyleme (yabancı dili kullanarak davranışta bulunmaya) odaklanan iletişimsel yaklaşımda tek başına bağlamsız cümleler üzerinde çalışmak yerine gerçek metinler ve konuşmalar ön plana çıkmaktadır (Baliuk vd. 2018: 3).

İletişimsel yaklaşım, gerçek hayattan örnekler, gerçek hayattan materyaller ve bu yaklaşımla düzenlenen sınıf ortamı ve aktivite tiplerinin öğrenmenin kalıcılığını pekiştireceğini savunur. Öğrenmenin kalıcılığını pekiştirmede bir diğer önemli etmen ise yapılan aktivitelerin aynı zamanda anlamlı bir iletişimi olanaklı kılmasıdır. (Akpınar Dellal ve Çınar 2011:24) 
Bu söylemden elde edilebilecek bir çıkarım sınıfın, gerçek hayat ve dil için okul haline gelmesi gerektiğidir. Tüm etkinlikler, uygulanan görevler buna uygun olarak belirli dil yapısının öğrenilmesini ve aynı zamanda iletişimsel ve anlamlı davranışta bulunmayı da amaçlamaktadır (bkz. Weskamp 2004). Trim vd.'ne (2001) göre dil kullanımı, birey ve sosyal aktör olarak çeşitli edinçleri özellikle de iletişimsel dil edincini geliştiren insan davranışlarını kapsamaktadır. Ayrıca iletişsimsel edincin öğrencilerin davranışta bulunmasına katkı sağladığını ve bunun için de yabancı dilin bir araç olduğunu belirtmektedir. "İletişimsel yeti, bir dil toplumu ile iletişim kurmak için gerekli bilgiler ve bunların kullanılması için gerekli becerilere sahip olma anlamına gelmektedir" (Aktaş 2005: 90). Güneş (2011: 143) ise son zamanlarda dilin sosyal bir etkileşim arac1 olarak görüldügünü ifade etmiştir. Sosyal aktörler olarak görülen öğrenciler toplumda değişik rol ve görevleri gerçekleştirmektedir. Bu görevlerin gerçekleşmesinde yabancı dil araç olarak kullanılmaktadır. Yabancı dil öğretiminde de öğrencilerin hem dilsel hem de bilişsel, duygusal, sosyal becerilerinin gelişmesine yönelik etkinlik ve görevler ön plana çıkmaktadır. Yabancı dil derslerinde öğrenciler bu görevleri etkinliklerle yerine getirirken etkileşim gerçekleşmektedir.

Funk vd. (2014) etkileşim kavramını, birbirleriyle ilişkili eylemler olarak tanımlamaktadır. Lingyan'a (2016) göre de sınıf içindeki veya gruptaki ders etkileşimler, farklı öğretim ve öğrenme hedefleri için firsatlar sunar. Amaç dilin girdisi ve çıktısı, geri bildirim veya öğrenenlerin amaç dildeki iletişime katılımı bu hedeflere örnek olarak gösterilebilir.

Sınıf ortamında öğrenme-öğretme sürecini daha etkili kılma bakımından öğretmenöğrenci etkileşimi kadar, öğrenci-öğrenci etkileşimi de önemlidir. Öğrenci-öğrenci etkileşiminin yapılandırılma biçimi, öğrencilerin öğrenme düzeylerini; öğretmene ve okula karşı tutumlarını; birbirleri hakkındaki düşüncelerini ve özsaygılarını önemli ölçüde etkileyebilmektedir. (Ekinci 2015: 93)

Etkileşim, derste öğrencinin metinle uğraşması veya bir görevde yer alması olarak ifade edilebilir. $\mathrm{Bu}$ kapsamda öğretmenler görevleri ve çalışma şekillerini yönlendirir. Etkileşimin sağlanmasında öğretmenler yönergeleri araç olarak kullanır. Çünkü yönergeler, görevleri ve alıştırma türlerini işaret eder. Öğretmen ise farklı görevleri ve alıştırma türlerini uygulayarak etkileşimin gerçekleşmesine ve öğrencilere firsat eşitliği sunulmasına katkı sağlamaktadır. Bu durumda öğretmen organizatör konumundadır. Örneğin; Almanca ders kitabındaki "Hayalindeki meslek nedir? Grup çalışması yaparak bir poster hazırlayın!" (Was ist dein Traumberuf? Arbeitet in Gruppen und macht ein Poster!) (bkz. Yılmaz Yiğit 2019) şeklindeki bir yönerge öğrencileri grup çalışmasına ve bir ürün ortaya koymaya yönlendirmektedir. Ancak bu görevleri gerçekleştirmek için öğrencilere ne kadar süre verileceğini, grubun kaç kişiden oluşacağını, görev dağılımının ne şekilde yapılacağı, etkileşiminin biçimini öğretmen belirler. $\mathrm{Bu}$ yönergelerin verilmesinde sosyal formlar önemli bir rol oynamaktadır.

Schwerdtfeger ve Meese'ye (2001) göre sosyal formların bulunmadığ veya yabancı dil dersinden söz edilemez. Sosyal formlar, derste öğretmenlerin öğrencilerle ya da öğrencilerin birbirleriyle olan ilişkilerini düzenlemektedir. Ayrıca 
sosyal formlar bir yandan sosyal süreci harekete geçirirken diğer yandan da bilişsel öğrenme süreçlerini yönlendirmektedir. $\mathrm{Bu}$ sosyal formlar aşağıdaki gibi gruplandırılmıştır:

1- Düz anlatım (Frontalunterricht): Dersin merkezinde öğretmen bulunur. Öğretmen öğrencilere konuyu anlatır, sorular sorar ve farklı öğrenciler soruları yanıtlar. Öğrenciler arasında da sorular sorulur ve cevaplanır. Burada öğretmen-öğrenci etkileşimi olduğu kadar öğrenciöğrenci etkileşimi de söz konusudur. (Funk vd. 2014: 58)

2- Grup çalışması (Gruppenarbeit): Grup çalışması için öğrenciler gruplara ayrılır. Gruplarda verilen aynı görevlerin yanı sıra farklı görevler üzerine de çalışılmaktadır. Bu durumda iş bölümü odaklı grup çalışması söz konusudur. Öğrenciler kendileri için oluşturulan çalışma görevlerini serbestçe yerine getirmektedir. Grup çalışmasının başarısı için temel koşul, öğretmenin öğrencilere küçük adımlı talimatlar ve kontrol olmadan bile görevleri tamamlayabilmelerine duyduğu güvendir. Bu öğretme ve öğrenme anlayışı öğrenci özerkliği kavramına uymaktadır. (a.g.y. 2014: 68)

3- Akran çalışması (Partnerarbeit): Öğrenciler ikili grup oluşturarak her öğrenci bir diğer öğrenci ile yardımlaşarak alıştırmaları ve görevleri gerçekleştirmektedir. Akran çalışmasında, öğrenciler arasında bilgi ve fikir alış verişi söz konusudur. Ayrıca akran çalışması, zaman tasarrufuna ve içeriğin anlamlı olmasına olanak sağlar. (a.g.y. 2014: 67)

4- Bireysel çalışma (Einzelarbeit): Öğrenciler edinilen bilgileri anlayabilir, pekiştirir ya da bunları sorun çözücü şekilde tartışabilir. $\mathrm{Bu}$ sosyal form öğrencilere bireysel olarak çalışma imkânı sunar ve genellikle okuma ve dinleme alıştırmalarında bulunmaktadır. (a.g.y. 2014: 61-62)

Sosyal formlar, yabancı dil öğrenme sürecinde öğrencilerin hem bilgileri zihninde yapılandırmasına ve anlamlandırmasına hem de etkileşim içinde öğrenmesine olanak sağlayan etkinlikleri kapsamaktadır. Bu bağlamda sosyal formlar yapılandırmacı yaklaşım ile paralellik göstermektedir.

Yapılandırıcı yaklaşımda etkinlik tür veya biçiminde zorlama yoktur. Çeşitli tür veya tipte öğrenme etkinliği kullanılabilir. Etkinliklerin bireysel olduğu kadar grupla yapılmasına da dikkat edilir. Örneğin öğrencinin sadece kitap okuyarak, öğretmeni dinleyerek bilgi ve becerilerini geliştirmesi yerine arkadaşlarıyla tartışarak, görüşlerini açıklayarak, sorgulayarak ve uygulayarak öğrenme sürecine aktif katılmasına ağırlık verilir. (Güneş 2011: 145) 
Öğrenme sürecinde öğrencilerin etkinliklerini yönlendiren ders kitaplarındaki yönergeler ise derslerde hangi sosyal formların kullanılacağına da işaret etmektedir. Örneğin; "İkişerli olarak çalışın ve yaptıklarınızı sınıfta anlatın!” (“Arbeitet zu zweit und berichtet es in der Klasse!") (bkz. Yılmaz Yiğit 2019) şeklindeki bir yönerge öğrencileri akran çalışmasına (Partnerarbeit) yönlendirmektedir. Ayrıca yönergeler öğrencilerin yabancı dili kullanarak hangi görevleri gerçekleştirmeleri gerektiğini de belirtir. Görevler yabancı dil derslerinin iletişimsel öğrenme amaçlarıdır, örneğin nasıl yol tarifi sorabilirim?, Okuduğumu bir başkasına nasıl anlatabilirim?, Özgeçmişimi nasıl yazabilirim? gibi (bkz. Funk vd. 2014). Görevler önceden çalışma kitabındaki boşlukları doldurma ya da soru ve cevap öğretimi anlamına gelmekteydi. Buna karşın yeni öğretim materyalleri öğrencilerin yaratıcılığının ön planda olduğu görevlerle doludur (bkz. Weskamp 2004). "Aileni tanıt ve konuyla ilgili bir metin yaz!” (“Stell deine Familie vor! Schreib einen Text!”) (bkz. Yılmaz Yiğit 2019) şeklindeki yönerge, görev olarak yazma eylemine yönlendirmektedir. Alıştırmalar ise görevlerin gerçekleşmesi için odak noktasını oluşturmaktadır. Görüldüğü gibi yabancı dil öğretiminde etkileşimli bir uygulama, dilin kurallarının doğrudan öğretilmesi yerine görevler aracılığıyla öğrencilerin aktif öğrenmesini destekleyerek gerçekleşmektedir.

Funk vd. (2014) göre alıştırmalar; sözcük dağarcığını, telaffuzu, yapıları ya da yalnız becerileri doğrudan yöneterek görevlere hazırlamaktadır. Böylece bir alıştırmanın en önemli ölçütü belirlenir: Alıştırmalar, öğrenenleri bir göreve hazırlamak zorundadır. Alıştırmalar, dilbilgisi ve sözcük dağarcığı bağlamında dilsel beceriler ile edinçlerin gelişmesine katkı sağlarken, görevler yabancı dilde iletişim kurarak eylemde bulunmayı mümkün kılmaktadır. Yabancı dildeki ifadelerin doğruluğu ise ikinci planda kalmaktadır (bkz. Thonhouser 2010). Görevler ve alıştırmalar öğrenenlerin iletişim için gerekli edinçleri adım adım oluşturmasına hizmet etmektedir. Dolayısıyla iletişimsel edinç geliştirmeye yönelik görevlerin ve alıştırmaların derslerde uygulanması ön plana çıkmaktadır. Çünkü günümüzdeki yabancı dil öğretiminde amaç öğrencilerin aktif şekilde bilgileri zihninde organize ederek yabancı dilde anlamlı iletişim kurabilmesidir. Öğrencilerin dilsel, bilişsel ve sosyal becerilerinin dikkate alınmasını belirten Ortaöğretim Almanca Dersi Öğretim Programı'na (2018) göre alıştırmalar ilginç, anlamlı ve öğrenenin bilişsel becerilerini teşvik edici olmalıdır.

\section{Amaç ve Araştırma Soruları}

Çalışmanın amacı Ortaöğretim Almanca derslerinde "Plus+ Deutsch A1.1" Almanca ders kitabındaki iletişimsel edinç geliştirmeye yönelik alıştırma türlerinin derslerde uygulanma durumunun belirlenmesidir. $\mathrm{Bu}$ doğrultuda aşağıdaki sorulara yanıt aranmıştır:

1- "Plus+ Deutsch A1.1" adlı Almanca ders kitabında yer alan alıştırma türlerinin derslerde uygulanma durumu nedir? 
2- "Plus+ Deutsch A1.1" adlı Almanca ders kitabındaki alıştırma türlerinin derslerde uygulanma durumuna yönelik öğretmen görüşleri nelerdir?

3- "Plus+ Deutsch A1.1" adlı Almanca ders kitabındaki alıştırma türlerinin derslerde uygulanma durumuna yönelik öğrenci görüşleri nelerdir?

\section{Önem ve Sayıltılar}

Özbal ve Genç (2019) araştırmasında "İstanbul Yabancılar İçin Türkçe”, "Yedi İklim Türkçe", "Gazi Yabancılar İçin Türkçe" ve "Yeni Hitit Yabanc1lar İçin Türkçe" A1-A2 ders ve çalışma kitaplarında yer alan alıştırma yönergeleri 5 farklı tema (uzun/kısa cümle kullanımı, kullanılan kip, tematik başlık kullanımı, örnek kullanımı ve kavram birlikteliği) altında incelemiştir. Zengin (1995) "Türkçe Öğreniyoruz I, II, III ve IV" ders kitaplarındaki alıştırma türlerini incelenmiş ve eksik kalan yönler için yeni alıştırma tipleri oluşturmuştur. Almanca öğretiminde iletişimsel edinç geliştirme bağlamında alıştırma türlerinin incelendiği bir araştırmaya alan yazında rastlanmamıştır. $\mathrm{Bu}$ çalışma hem alan yazındaki bu boşluğu doldurması hem de alıştırma türlerine ilişkin derinlemesine bir araştırma olması bakımından bir özgünlük değeri taşıdığı düşünülmektedir. Öğretmenlerin "Plus+ Deutsch A1.1" adlı Almanca öğrenci ders kitabındaki tüm alıştırma türlerini uygulama yeterliliğine sahip olduğu, öğretmenlerin ve öğrencilerin araştırma için hazırlanan sorulara samimi ve doğru şekilde yanıt verdiği düşünülmüştür.

\section{Yöntem}

\section{Araştırma Modeli}

$\mathrm{Bu}$ nitel çalışma, durum çalışması yönteminden tek durum çalışmasına göre desenlenmiştir. "Durum çalışması, bir durum hakkında detaylı bilgi toplamayı ve birçok veri toplama aracının bir arada kullanılmasıyla çalışmanın yürütülmesini amaçlayan başlı başına bir yöntemdir" (Kaleli Yılmaz 2015: 266). Bu bağlamda durum çalışmasının araştırma yapılmak istenen bir durum hakkında detaylı bir araştırma ve bilgi edinme imkânı tanıyan, birçok veri toplama aracının bir arada kullanıldığı bir yöntem olduğu söylenebilir. "Başka bir deyişle, durum çalışması güncel bir olayı derinlemesine ve bütünsel olarak gerçekçi dünya perspektifinden incelemeyi gerektirir" (Akar 2016: 113).

\section{Çalışma Grubu}

Araştırma için zaman ve mekân sınırlılığı olmasından dolayı seçkisiz olmayan örnekleme yöntemlerinden uygun örnekleme yaklaşımı temel alınarak çalışma grubu oluşturulmuştur. "Uygun örnekleme, zaman, para ve işgücü açısından var olan 
sınırlılıklar nedeniyle örneklemin ulaşılabilir, kolay uygulama yapılabilir birimlerden seçilmesi yöntemidir" (Büyüköztürk vd. 2019: 103). Araştırmanın çalışma grubu "Plus+ Deutsch A1.1" adlı Almanca ders kitabı, 2019-2020 Eğitim-Öğretim Y1l Bahar Dönemi İzzettin Çalışlar Anadolu Lisesi, Vala Gedik Anadolu Lisesi ve Ahmet Avcı Anadolu Lisesi'nde görev yapan Almanca öğretmenleri ile bu okullarda öğrenim gören 9. ve 10. sınıf öğrencileri ile sınırlandırılmıştır. Çalışma grubunda her 3 lisede görev yapan temsili 3 öğretmen araştırmaya katılmış, öğrencilerin ise 194'üne ulaşılmıştır. Tablo 1 'de ise araştırmaya katılan öğrencilerin okullara, cinsiyete ve sınıf düzeylerine göre dağılımları yer almaktadır.

\begin{tabular}{lcccc}
\hline & & $\mathrm{n}$ & $\%$ & Toplam \\
\hline \multirow{3}{*}{ Okullar } & İzzettin Çalışlar Anadolu Lisesi & 46 & $\% 24$ & \\
& Vala Gedik Anadolu Lisesi & 24 & $\% 12$ & $194(\% 100)$ \\
& Ahmet Avcı Anadolu Lisesi & 124 & $\% 64$ & \\
\multirow{2}{*}{ Cinsiyet } & Kadın & 130 & $\% 67$ & $194(\% 100)$ \\
& Erkek & 64 & $\% 33$ & $194(\% 100)$ \\
Sinıf Düzeyi & 9. Sınıf & 85 & $\% 44$ & $\% 56$ \\
\hline
\end{tabular}

Tab. 1: Araştırmaya Katılan Öğrencilerin Okullara, Cinsiyete ve Sınıf Düzeylerine Göre Dağılımları

\section{Veri Toplama Araçları}

Çalışmada veri toplama aracı olarak doküman, anket ve görüşme kullanılmıştır. Bu çalışmada "Plus+ Deutsch A1.1" adlı Almanca ders kitabında bulunan konu alanlarındaki alıştırma türleri ele alındığı için birinci veri toplama aracı olarak 20192020 Eğitim-Öğretim y1lı güz ve bahar döneminde Ortaöğretim 9. ve 10. sinıflarda okutulan "Plus+ Deutsch A1.1" Almanca öğrenci ders kitab1 doküman olarak kullanılmıştır. Toplamda 8 üniteden oluşan "Plus+ Deutsch A1.1" Almanca ders kitabının 1., 2., 3. ve 4. üniteleri 9. Sinıflarda, 5., 6., 7. ve 8. üniteleri ise 10. sinıflarda okutulmaktadır.

İkinci veri olan anket çalışması öğrencilere uygulanmıştır. Anketin hazırlanmasında Funk vd. (2014) tarafından gruplandırılan alıştırma türleri ölçüt olarak kullanılmış ve araştırmacılar tarafından iletişimsel edinç bağlamında birinci veri olan dokümandan yararlanılmıştır. $\mathrm{Bu}$ dokümandan alıştırma türlerinin resimleri anket maddeleri ile birlikte verilmiştir. Ankette hem 9. sınıf hem de 10. sınıf konularına yönelik toplamda 14 madde yer almaktadır. Ancak anket iki farklı sınıfta öğrenim gören öğrencilere uygulanacağı için anket maddeleri sınıf düzeyindeki konulara göre ikiye bölünmüş ve "Anket 1" ve "Anket 2" olarak adlandırılmıştır. Bu durumda 1., 2., 3., 4., 5., 6. ve 7. maddeler 9. Sinıflara uygulanacak "Anket 1"de yer almaktadır. 8., 9., 10., 11., 12., 13. ve 14. maddeler ise 10. siniflara uygulanacak "Anket 2"de bulunmaktadir. Tablo 2'de anket numarası, anketin uygulanacağı öğrencilerin sınıf düzeyi, anket ölçütleri ve anket maddelerine ilişkin bilgiler bulunmaktadır. 


\begin{tabular}{|c|c|c|c|c|}
\hline $\begin{array}{l}\text { Anket } \\
\text { No }\end{array}$ & $\begin{array}{l}\text { Anketin } \\
\text { Uygulanacağı } \\
\text { Öğrencilerin } \\
\text { Sınıf Düzeyi }\end{array}$ & & Anket Ölçütleri & Anket Maddeleri \\
\hline \multirow{7}{*}{ ت } & \multirow{7}{*}{ 9. Sinif } & $\begin{array}{l}\text { İletişimsel } \\
\text { edinç } \\
\text { bağlamında }\end{array}$ & Ürün tanıtımı yapma & $\begin{array}{l}\text { 1. Ders konusuna ilişkin bir } \\
\text { ürün (poster gibi) ortaya konulur ve } \\
\text { sınıfta tanıtımı yapılır }\end{array}$ \\
\hline & & $\begin{array}{l}\text { seçilen } \\
\text { alıştırmalar }\end{array}$ & $\begin{array}{l}\text { Üç veya daha fazla } \\
\text { kişilik grup çalışması }\end{array}$ & $\begin{array}{l}\text { 2. Üç ve daha fazla kişiden } \\
\text { oluşan gruplarda çalışmalar yapilır. }\end{array}$ \\
\hline & & \multirow{5}{*}{$\begin{array}{l}\text { Funk } \\
\text { vd.’ne göre } \\
\text { alıştırma } \\
\text { türleri }\end{array}$} & $\begin{array}{l}\text { Alımlamaya yönelik } \\
\text { alıştırmalar (rezeptive } \\
\text { Übungen) }\end{array}$ & $\begin{array}{l}\text { 3. Dinleme yapilır } \quad \text { ve } \\
\text { sonrasında metin okunur. }\end{array}$ \\
\hline & & & $\begin{array}{c}\text { Üretmeye yönelik } \\
\text { alıştırmalar (produktive } \\
\text { Übungen) }\end{array}$ & $\begin{array}{l}\text { 4. Verilen örnek bir metin için } \\
\text { cevap yazılır. }\end{array}$ \\
\hline & & & $\begin{array}{l}\text { Yeniden üretmeye } \\
\text { yönelik alıştırmalar } \\
\text { (reproduktive Übungen) }\end{array}$ & $\begin{array}{l}\text { 5. Belirli talimatlara göre } \\
\text { cümleler ya da metinler oluşturulur. }\end{array}$ \\
\hline & & & $\begin{array}{l}\text { Kapalı uçlu alıştırmalar } \\
\text { (geschlossene Übungen) }\end{array}$ & 6. Eşleştirmeler yapılır. \\
\hline & & & $\begin{array}{l}\text { Biçim odaklı alıştırmalar } \\
\text { (formfokussierte } \\
\text { Übungen) }\end{array}$ & $\begin{array}{l}\text { 7. Verilen cümlelerdeki fiiller } \\
\text { ya da dilbilgisi yapıları işaretlenir. }\end{array}$ \\
\hline \multirow{7}{*}{ 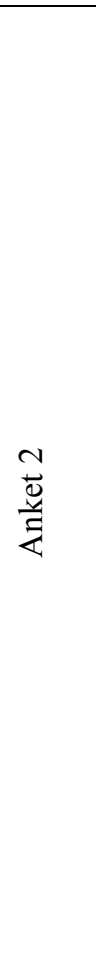 } & \multirow{7}{*}{ 10. Sinif } & \multirow{3}{*}{$\begin{array}{l}\text { İletişimsel } \\
\text { edinç } \\
\text { bağlamında } \\
\text { seçilen } \\
\text { alıştırmalar }\end{array}$} & $\begin{array}{l}\text { Soru sorma ve cevap } \\
\text { verme }\end{array}$ & $\begin{array}{lrlll}8 . & \text { Sinifta } & \text { sorular } & \text { sorulur } & \text { ve } \\
\text { cevaplar verilir. } & & & \end{array}$ \\
\hline & & & Canlandirma & $\begin{array}{l}9 . \quad \text { Örnek olarak verilen } \\
\text { konuşmalar (alışveriş diyalogları gibi) } \\
\text { sınıfta canlandırılır. }\end{array}$ \\
\hline & & & İkili grup çalışması & $\begin{array}{l}\text { 10. Konuşmalar (Diyaloglar) } \\
\text { ikişerli gruplar halinde okunur. }\end{array}$ \\
\hline & & \multirow{4}{*}{$\begin{array}{l}\text { Funk } \\
\text { vd.'ne göre } \\
\text { alıştırma } \\
\text { türleri }\end{array}$} & $\begin{array}{c}\text { Yeniden üretme- } \\
\text { üretmeye yönelik } \\
\text { alıştırmalar } \\
\text { (reproduktiv-produktive } \\
\text { Übungen) }\end{array}$ & $\begin{array}{l}\text { 11. Örnek olarak verilen bir } \\
\text { metne yönelik yazılı ve sözlü } \\
\text { cevaplandırılacak alıştırmalar yapılır. }\end{array}$ \\
\hline & & & $\begin{array}{l}\text { Açık uçlu alıştırmalar } \\
\text { (offene Übungen) }\end{array}$ & $\begin{array}{l}\text { 12. Özgür cevaplama imkânı } \\
\text { sunan alıştırmalar yapılır. }\end{array}$ \\
\hline & & & halboffene Übungen & $\begin{array}{l}\text { 13. Birkaç farklı şekilde cevaplar } \\
\text { sunan alıştırmalar yapılır. }\end{array}$ \\
\hline & & & $\begin{array}{l}\text { İçerik odaklı alıştırmalar } \\
\text { (inhaltsbezogene } \\
\text { Übungen) }\end{array}$ & $\begin{array}{l}\text { 14. Verilen metnin konusuna ya } \\
\text { da içeriğine yönelik alıştırmalar } \\
\text { yapılır. }\end{array}$ \\
\hline
\end{tabular}

Tab. 2: Anket Numarası, Anketin Uygulanacağı Öğrencilerin Sınıf Düzeyi, Anket Ölçütleri ve Anket Maddelerine İlişkin Bilgiler 
Anketteki maddelerin işaretlenme seçenekleri ise derecelendirme ölçeğine göre oluşturulmuştur. Çünkü "Derecelendirme ölçekleri, bireyin anket maddesine ilişkin cevaplarını (tepkilerini, birbirini mantıksal bir düzen içinde izleyen ölçek noktaları cevap seçenekleri) üzerinde kendisine en uygun geleni seçerek göstermesini sağlar" (Büyüköztürk vd. 2019: 134). Anketteki maddeler "Hiç uygulanmıyor", “Arada bir uygulanıyor", "Çoğunlukla uygulanıyor" ve "Her zaman uygulanıyor" seçenekleri ile işaretlenmektedir. Büyüköztürk vd. (2019: 144) derecelendirme ölçeklerinde ölçek noktalarının (seçeneklerinin) fazla olmasının güvenirliği olumlu yönde etkilemesine rağmen psikometrik araştırmalara göre seçeneklerin altı veya yediden fazla olması halinde cevaplayıcının güvenilir olarak ayrım yapamadığını ve genellikle dört veya beş ölçek noktası sunulduğunda yeterince güvenilir bir sonuca varıldığını ifade etmiştir. Hem Büyüköztürk vd.'nin görüşüne dayanarak hem de cevaplayıcının nötr noktasına kolayca yönelmemesi için ankette dört ölçek noktası oluşturulmuştur. Koronavirüs (Covid-19) pandemisi nedeniyle 2019-2020 Eğitim-Öğretim Yılı Bahar döneminde tüm öğretim kademelerindeki okullar kapalı olduğu için veriler, Google Drive'daki "Google formlar" üzerinden çevrimiçi hazırlanan ve web bağlantısı olarak "Whatsapp" sosyal medya ile öğrencilere iletilen elektronik anket formu aracılığıyla toplanmıştır.

Üçüncü veri ise öğretmenler ve öğrencilerle gerçekleştirilen bireysel görüşmelerde kullanılan "Almanca Dersi Öğretmen Görüş Alma Formu” ve "Almanca Dersi Öğrenci Görüşme Formu” aracılığıyla toplanmıştır. Bireysel görüşme formları hazırlanırken görüşme türlerinden standartlaştırılmış açık uçlu görüşme (Yıldırım ve Şimşek 2018) temel alınmıştır. Araştırmaya katılan tüm öğrencilerle birebir görüşme gerçekleştirilemeyeceğinden dolayı seçkisiz olmayan örnekleme yöntemlerinden uygun örnekleme yaklaşımına dayanarak seçilen 6 öğrenci ile bireysel görüşmeler yapılmıştır. Hem öğretmenlerle hem de öğrencilerle yapılan bireysel görüşmelerde Zoom uygulaması kullanılmıştır. Katılımcılara öncelikle görüşmenin amacı açıklanmış ve sorulara verilen yanıtların araştırmacı tarafindan ses kaydı yapılması konusunda katılımcılardan izin alınarak bireysel görüşmeler sesli olarak kayıt altına alınmıştır. Sonrasında öğrencilere “Almanca Dersi Öğrenci Görüşme Formu”nda yer alan sorular yöneltilmiştir. Öğrencilerle yapılan her bireysel görüşmeler 3 ila 8 dakika arasında değişmiştir. Çalışma grubundaki üç Almanca öğretmeni “Almanca Dersi Öğretmen Görüş Alma Formu'ndaki soruları yanıtlayarak görüşlerini ifade etmiştir. Her bir görüşme yaklaşık 10 dakika sürmüştür.

\section{Verilerin Analizi}

Birinci veri olan dokümandan veriler için Bloom'un taxinomisi (bkz. Anderson 2001) ve Funk'un (2014) tipolojileri kullanılarak sınıflandırma tekniği ile analiz edilmiştir. İkinci veri olan anketten elde edilen bulgular $\mathrm{n}$ ve $\%$ olarak hesaplanmıştır. Bireysel görüşmelerin analizinde ise içerik analizi yöntemi kullanılmıştır. "İçerik analizinde temelde yapılan işlem, birbirine benzeyen verileri belirli kavramlar ve temalar çerçevesinde bir araya getirmek ve bunları okuyucunun anlayabileceği bir biçimde düzenleyerek yorumlamaktır" (Yıldırım ve Şimşek 2018: 242). Zoom programında 
kayıt altına alınan tüm öğretmen ve öğrenci görüşmeleri araştırmacı tarafından katılımcılar için hazırlanan görüşme formlarında yazılı metinler haline getirilmiş, Excel programı aracılığıyla yazılı metin olarak aktarılmış, araştırmacı tarafından ana temalar ve alt temalar halinde toplanmış ve yorumlanmıştır. Etik kurallardan dolayı araştırmaya katılan öğretmenler AÖ (Almanca Öğretmeni) kısaltmasıyla AÖ1, AÖ2 ve AÖ3 olarak kodlanırken, öğrenciler ise Ö1, Ö2, Ö3, Ö4, Ö5, Ö6 şeklinde kodlanmış ve etik kurul kararı doğrultusunda uygulanmıştır.

\section{Bulgular ve Tartışma}

Ders kitapları, hazırlandıkları dönemde ortaya çıkan yabancı dil öğretim yöntemlerini yansıtmaktadır. Yabancı dil öğretiminde iletişimsel yaklaşımın önem kazanması ile birlikte ilk olarak bu yaklaşımın özelliklerini yansıtan "Deutsch Aktiv" Almanca ders kitabı hazırlanmıştır. Aynı zamanda iletişimsel edinci geliştirmeye yönelik alıştırma çeşitlerinin bir tipoloji ${ }^{1}$ bağlamında verildiği kaynaklar öncelikle Neuner vd. (1981) ile Doyé (1988), sonrasında Häussermann ve Piepho (1996), günümüzde ise Funk vd. (2014) tarafından oluşturulmuştur. Bu bağlamda alıştırma türlerinin belirli bir dizge takip ettiği görülmektedir.

Anderson vd.'ne (2001) göre Bloom'un bilişsel süreç boyutları yeniden düzenlenerek kategorilere ayrılmıştır. Burada amaç öğrenme hedeflerinde bulunan öğrenci bilişsel süreçlerinin kapsamlı bir şekilde sınıflandırılmasıdır. Kategoriler, hedeflerde en yaygın olarak bulunan bilişsel süreç basamağından (hatırlama), anlama ve uygulama basamağı aracılığıyla daha az bulunan basamaklara doğru (analiz, değerlendirme ve yaratma) sıralanmaktadır.

1- Hatırlama: Konu ile ilgili bilgileri uzun süreli hafizadan geri getirme anlamina gelmektedir.

2- Anlama: Sözlü, yazılı ve grafikle gösterilen iletişimi içeren öğretim mesajlarının anlamını oluşturmak olarak tanımlanmaktadır.

3- Uygulama: Belirli bir yöntemi kullanma ya da gerçekleştirme anlamına gelmektedir.

4- Analiz: Bütünü oluşturan parçaları ayırmayı, parçaların birbirleriyle ve ayrıca genel bir yapı veya amaç ile nasıl ilişkili olduğunu belirlemeyi ifade eder.

5- Değerlendirme: Ölçüt ve/veya standartlara dayanarak yargılarda bulunmak demektir.

\footnotetext{
1 "Bir alıştırma tipolojisi, alıştırmaların dersteki beceri ve yetenekler, iletişim durumları ve amaçları ile sosyal formlar bakımından öğrenme hedeflerine göre derlenmesi ve sınıflandırılmasını sağlar" (https://www.hueber.de/wiki-99-stichwoerter/index.php/\%C3\%9Cbungstypologie, son erişim tarihi: 21.12.2019).
} 
6- Yaratma: Yeni, tutarlı bir bütün oluşturmak veya orijinal bir ürün oluşturmak için öğeleri bir araya getirmeyi ifade eder (Anderson vd. 2001: 30). ${ }^{2}$

Bloom'un bilişsel öğrenme basamakları hem bilişsel öğrenme hem de yabancı dilde eylemde bulunma açısından önemli rol oynamaktadır. Bu açıdan Bloom'un bilişsel süreç basamaklarının "Plus+ Deutsch A1.1" (bkz. Y1lmaz Yiğit 2019) adlı Almanca ders kitabında yönerge düzeyinde bulunma durumu ele alınacaktır.

Örnek 1:

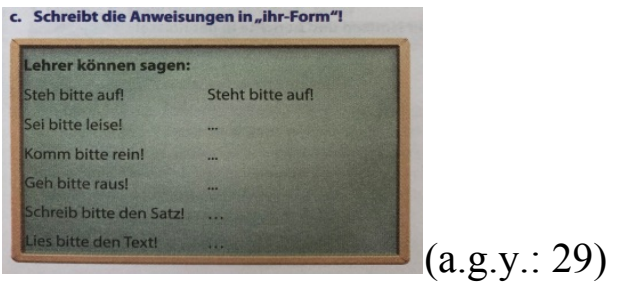

Örnek 1'deki yönerge hatırlama basamağındaki bir alıştırmaya yönlendirmektedir. Öğrenciler sadece "du (sen)" şahıs zamirine göre çekimlenen emir cümlelerini "ihr (siz)" şahıs zamirine göre çekimleyeceklerdir. Bu durumda öğrencilerden fiillerin "ihr" şahıs zamirine göre çekimlerini hatırlaması beklenmektedir.

Örnek 2:

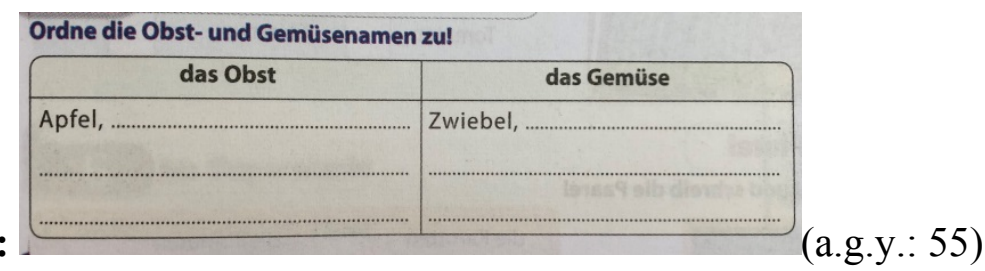

Örnek 2 şeklindeki bir yönerge, anlama basamağındaki alıştırmaya yönlendirmektedir. $\mathrm{Bu}$ alıştırmada öğrenciler öğrendikleri sebze ve meyve isimlerini sınıflandırarak yazacaklardır.

\section{Örnek 3:}

e. Schreib ein Rezept und lies in der Klasse vor!

Örnek 3 şeklindeki bir yönerge uygulama basamağındaki bir alıştırmaya yönlendirmektedir. Çünkü burada öğrenciden bir yemek tarifi yazması ve sınıfta okuması beklenmektedir. Öğrenci bu görevi yerine getirirken yemek tarifi konusunda öğrendiklerini uygulayacaktır.

\footnotetext{
2 Ayrıca detaylı tablo için bkz: Bümen, N. T. (2006). Program geliştirmede bir dönüm noktası: Yenilenmiş Bloom taksonomisi, Eğitim ve Bilim 31(142), 3-14. http://egitimvebilim.ted.org.tr/index.php/EB/article/view/837/189 (son erişim tarihi: 02.03.2021).
} 


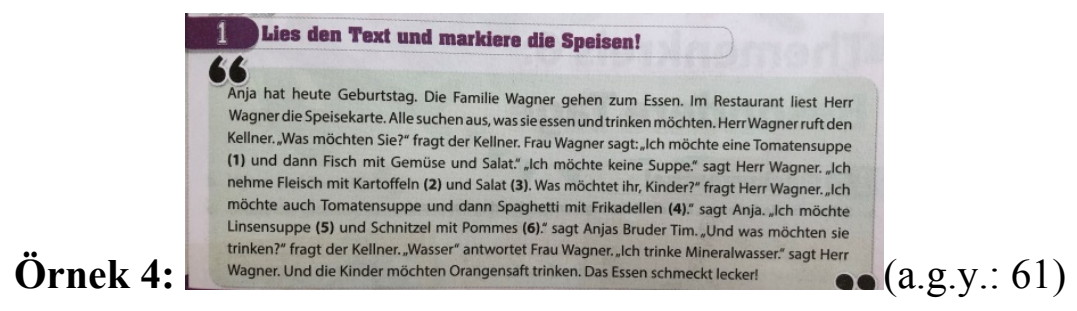

Örnek 4 şeklindeki bir alıştırma ise analiz basamağındadır. Burada öncelikle öğrenciler genel anlamda metni okumaya ve yiyecek isimleri işaretlemeleri yönlendirilmektedir. Burada öğrencilerin metni ayrıştırmaları gerekmektedir.

Örnek 5:

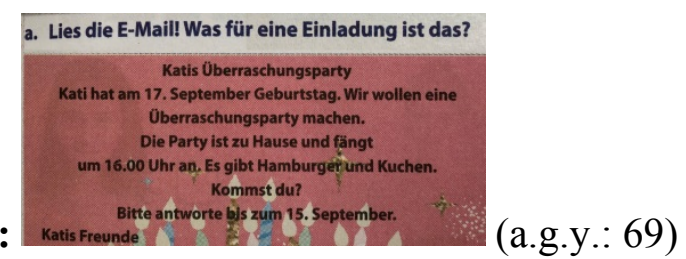

Örnek 5 şeklindeki bir yönerge ise değerlendirme basamağındadır. Burada öğrenciler okudukları e-postayı değerlendirecekler ve davetin ne için yazılmış olduğuna karar verecekler.

Örnek 6:

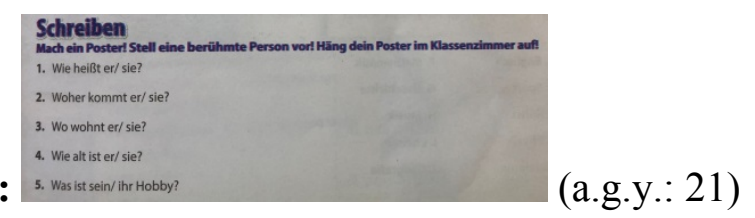

Örnek 6 şeklindeki bir yönerge ise yaratma basamağındadır. Öğrenciler bir poster hazırlayarak yeni bir ürün ortaya koyacaklar. Ünlü birini tanıtmada ise kişinin adı, nereden geldiği gibi bilgileri bir araya getirecekler.

Bu 6 örnek "Plus+ Deutsch A1.1" adlı Almanca ders kitabının (2019) Bloom taksonomisindeki tüm bilişsel alan basamaklarına yönelik alıştırma türlerini içerdiğini somut olarak göstermektedir. "Plus+ Deutsch A1.1" (bkz. Y1lmaz Yiğit 2019) adlı Almanca ders kitabındaki alıştırma türlerinin Funk vd. (2014) bulunma durumuna da bakmak gerekmektedir. Buna göre

1- Alımlamaya yönelik alıştırmalar (rezeptive Übungen): Bu tür alıştırmalarda sadece içeriği anlamak söz konusudur, bir metin dinlemek ya da okumak gibi. Öğrenenler kendi düşüncelerini üretmek zorunda değildir.

\section{Örnek 7: b. Hör noch einmal zu und lies mit! (a.g.y.: 16)}

2- Üretmeye yönelik alıştırmalar (produktive Übungen): Öğrencilerin dil ile yapabilecekleri her şeyi kullanarak dili kendilerinin üretmeleri teşvik edilir. 
Örnek 8:

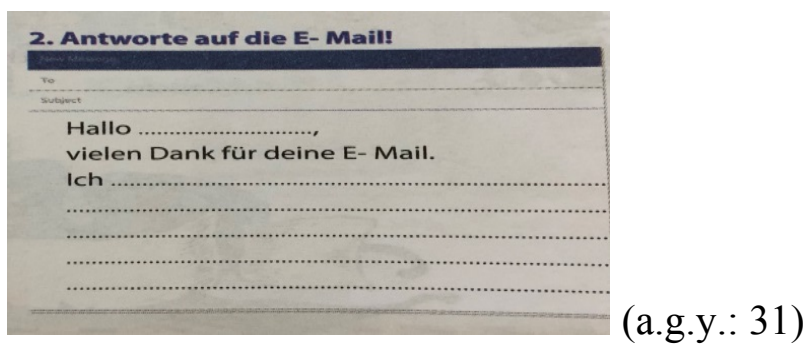

3- Yeniden üretmeye yönelik alı̧stırmalar (reproduktive Übungen): Öğrenenler belirli talimatlara göre cümleler ya da metinler üretir.

Örnek 9:

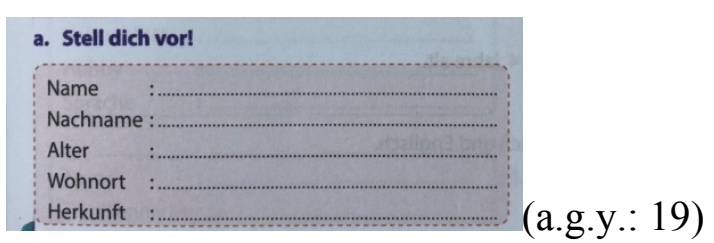

4- Yeniden üretme-üretmeye yönelik alıştırmalar (reproduktiv-produktive Übungen): Örnek bir metin verilir. Öğrenciler ona göre kendi yazılı veya sözlü metin oluştururlar.

\section{Örnek 10:}

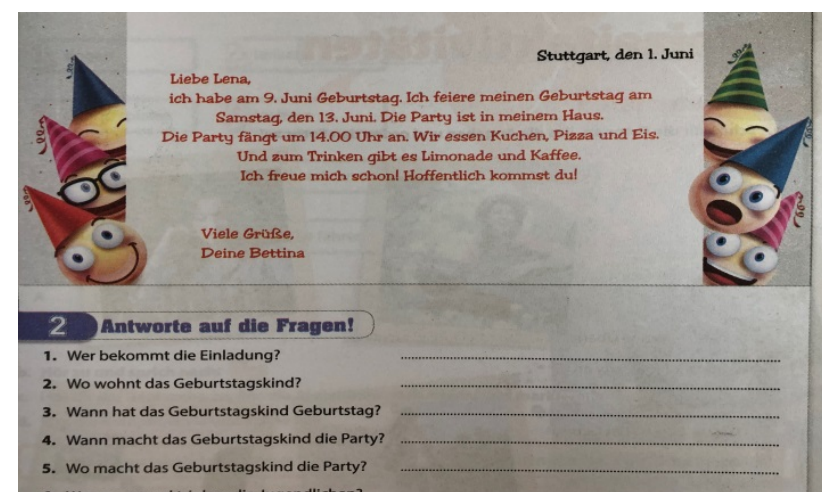

5- Açık uçlu alıştırmalar (offene Übungen): Bu tür alıştırmalar öğrenenlere özgür çalışma imkânı sunar. Birçok cevap seçenekleri vardır.

Örnek 11:

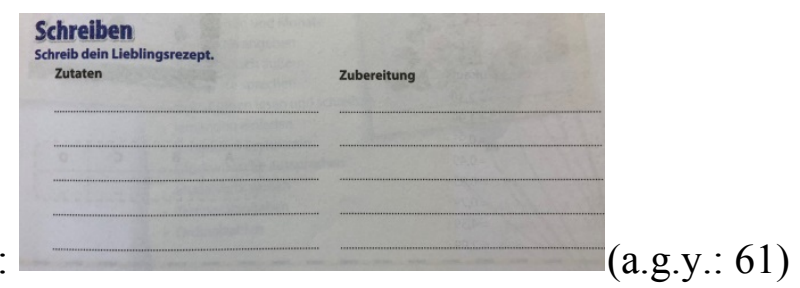

6- Yarı açık uçlu alıştırmalar (halboffene Übungen). Bu alıştırmalar bir dereceye kadar çeşitlilik ve seçenek sunar. Birden fazla çözüm veya cevap mümkündür.

Örnek 12:

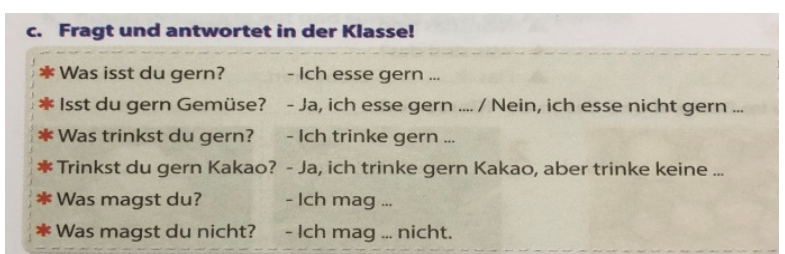

(a.g.y.: 55) 
7- Kapalı uçlu alıştırmalar (geschlossene Übungen): Bu tür alıştırmaların sadece tek bir çözümü/cevabı bulunmaktadır.

Örnek 13:

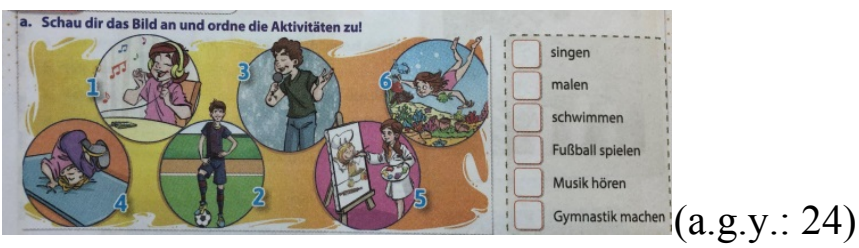

8- İçerik odaklı alıştırmalar (inhaltsbezogene Übungen): Öğrenenlerin dikkatini sözlü ya da yazılı metinlerin içeriğine yönlendirir.

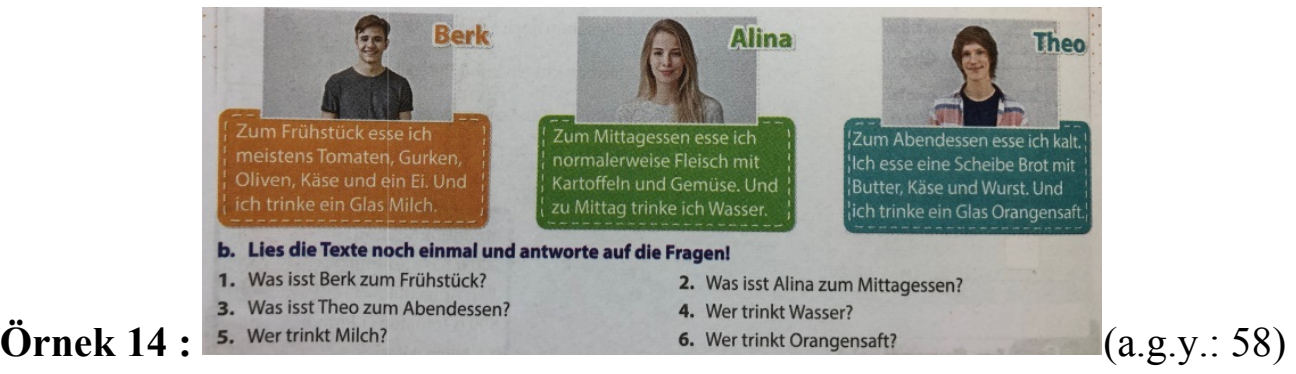

9- Biçim odaklı alıştırmalar (formfokussierte Übungen): Öğrenenler dilsel araçlara ve yapılara odaklanır.

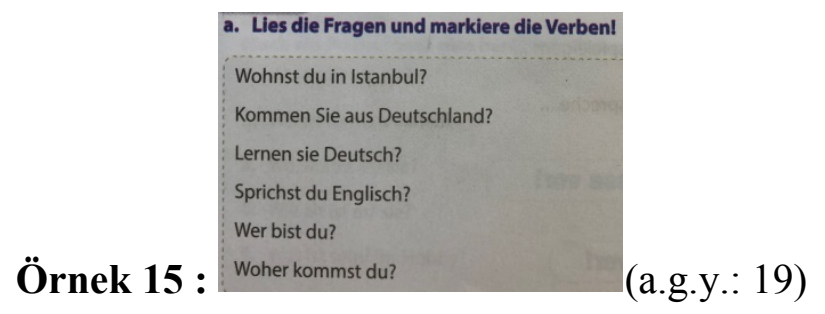

Ders kitabı dersler ve alıştırmalar için temel kaynak olduğundan liselerde okutulan "Plus+ Deutsch A1.1" adlı Almanca ders kitabındaki alıştırma türleri bilişsel anlamda Bloom'un yenilenen bilişsel süreç basamakları, iletişimsel anlamda da Funk vd. (2014)'nin belirlediği alıştırma türleri temel alınarak değerlendirilmiştir. Bu doküman incelemesi örneklerinden hareketle adı geçen ders kitabının öğrencilerin hem zihinsel gelişimi hem de iletişimsel edinç kazanması için alıştırma türlerinin uygun bulunduğu sonucuna varılmaktadır. Bu çalışmada ise alıştırma türlerinin ders içi etkileşim durumu ele alınacaktır.

Bu bölümde araştırma problemi doğrultusunda ilk olarak "Plus+ Deutsch A1.1" Almanca ders kitabında yer alan alıştırma türlerinin derslerde uygulanma durumuna ilişkin öğrencilere uygulanan anket sonucunda elde edilen bulgular yer almaktadır. Sonrasında ise öğrencilerle ve öğretmenlerle yapılan bireysel görüşmelere ilişkin bulgulara yer verilmiştir. 


\begin{tabular}{|c|c|c|c|c|c|}
\hline $\begin{array}{c}\text { Anket } \\
\text { Madde } \\
\text { No }\end{array}$ & Anket Maddeleri & 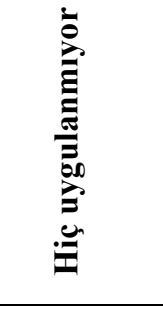 & 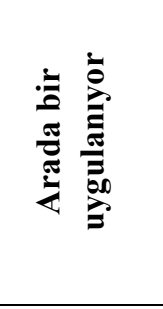 & 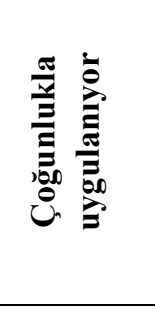 & 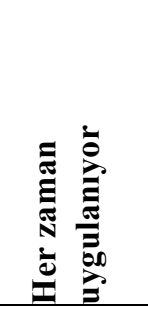 \\
\hline & & & & $\begin{array}{ll}\mathrm{n} & (\%)\end{array}$ & \\
\hline 1. & $\begin{array}{l}\text { Ders konusuna ilişkin bir ürün } \\
\text { (poster gibi) ortaya konulur ve } \\
\text { sınıfta tanıtımı yapılır. }\end{array}$ & $\begin{array}{c}7 \\
(\% 8.2)\end{array}$ & $\begin{array}{c}23 \\
(\% 27.1)\end{array}$ & $\begin{array}{c}25 \\
(\% 29.4)\end{array}$ & $\begin{array}{c}30 \\
(\% 35.3)\end{array}$ \\
\hline 2. & $\begin{array}{l}\text { Üç ve daha fazla kişiden } \\
\text { oluşan gruplarda çalışmalar } \\
\text { yapılır. }\end{array}$ & $\begin{array}{c}10 \\
(\% 11.8)\end{array}$ & $\begin{array}{c}33 \\
(\% 38.8)\end{array}$ & $\begin{array}{c}23 \\
(\% 27.1)\end{array}$ & $\begin{array}{c}19 \\
(\% 27.1)\end{array}$ \\
\hline 3. & $\begin{array}{l}\text { Dinleme yapilır ve sonrasinda } \\
\text { metin okunur. }\end{array}$ & $\begin{array}{c}2 \\
(\% 2.4)\end{array}$ & $\begin{array}{c}8 \\
(\% 9.4)\end{array}$ & $\begin{array}{c}27 \\
(\% 31.8)\end{array}$ & $\begin{array}{c}48 \\
(\% 5.5)\end{array}$ \\
\hline 4. & $\begin{array}{l}\text { Verilen örnek bir metin için } \\
\text { cevap yazılır. }\end{array}$ & $\begin{array}{c}4 \\
(\% 4.7)\end{array}$ & $\begin{array}{c}13 \\
(\% 15.3)\end{array}$ & $\begin{array}{c}30 \\
(\% 35.3)\end{array}$ & $\begin{array}{c}38 \\
(\% 44.7)\end{array}$ \\
\hline 5. & $\begin{array}{l}\text { Belirli talimatlara göre } \\
\text { cümleler ya da metinler } \\
\text { oluşturulur. }\end{array}$ & $\begin{array}{c}1 \\
(\% 1.2)\end{array}$ & $\begin{array}{c}5 \\
(\% 5.9)\end{array}$ & $\begin{array}{c}26 \\
(\% 30.6)\end{array}$ & $\begin{array}{c}53 \\
(\% 62.4)\end{array}$ \\
\hline 6. & Eşleştirmeler yapilır. & $\begin{array}{c}5 \\
(\% 5.9)\end{array}$ & $\begin{array}{c}3 \\
(\% 3.5)\end{array}$ & $\begin{array}{c}30 \\
(\% 35.3)\end{array}$ & $\begin{array}{c}47 \\
(\% 55.3)\end{array}$ \\
\hline 7. & $\begin{array}{l}\text { Verilen cümlelerdeki fiiller ya } \\
\text { da dilbilgisi yapıları } \\
\text { işaretlenir. }\end{array}$ & $\begin{array}{c}3 \\
(\% 3.5)\end{array}$ & $\begin{array}{c}9 \\
(\% 10.6)\end{array}$ & $\begin{array}{c}32 \\
(\% 37.6)\end{array}$ & $\begin{array}{c}41 \\
(\% 48.2)\end{array}$ \\
\hline 8. & $\begin{array}{l}\text { Sinifta sorular sorulur ve } \\
\text { cevaplar verilir. }\end{array}$ & $\begin{array}{c}6 \\
(\% 5.5)\end{array}$ & $\begin{array}{c}7 \\
(\% 6.4)\end{array}$ & $\begin{array}{c}31 \\
(\% 28.4)\end{array}$ & $\begin{array}{c}65 \\
(\% 59.6)\end{array}$ \\
\hline 9. & $\begin{array}{llr}\begin{array}{l}\text { Örnek olarak } \\
\text { konuşmalar }\end{array} & \begin{array}{r}\text { verilen } \\
\text { (alışveriş }\end{array} \\
\begin{array}{l}\text { diyalogları gibi) } \\
\text { canlandırılır. }\end{array} & & \end{array}$ & $\begin{array}{c}0 \\
(\% 0)\end{array}$ & $\begin{array}{c}10 \\
(\% 9.2)\end{array}$ & $\begin{array}{c}47 \\
(\% 43.1)\end{array}$ & $\begin{array}{c}52 \\
(\% 47.7)\end{array}$ \\
\hline 10. & $\begin{array}{l}\text { Konuşmalar (Diyaloglar) } \\
\text { ikişerli gruplar halinde } \\
\text { okunur. }\end{array}$ & $\begin{array}{c}0 \\
(\% 0)\end{array}$ & $\begin{array}{c}10 \\
(\% 9.2)\end{array}$ & $\begin{array}{c}33 \\
(\% 30.3)\end{array}$ & $\begin{array}{c}66 \\
(\% 60.6)\end{array}$ \\
\hline 11. & $\begin{array}{l}\text { Örnek olarak verilen bir } \\
\text { metne yönelik yazılı ve sözlü } \\
\text { cevaplandırılacak alıştırmalar } \\
\text { yapılır. }\end{array}$ & $\begin{array}{c}0 \\
(\% 0)\end{array}$ & $\begin{array}{c}13 \\
(\% 11.9)\end{array}$ & $\begin{array}{c}35 \\
(\% 32.1)\end{array}$ & $\begin{array}{c}61 \\
(\% 56)\end{array}$ \\
\hline 12. & $\begin{array}{l}\text { Özgür cevaplama imkânı } \\
\text { sunan alıştırmalar yapılır. }\end{array}$ & $\begin{array}{c}1 \\
(\% 0.9)\end{array}$ & $\begin{array}{c}12 \\
(\% 11)\end{array}$ & $\begin{array}{c}43 \\
(\% 39.4)\end{array}$ & $\begin{array}{c}53 \\
(\% 48.6)\end{array}$ \\
\hline
\end{tabular}




\begin{tabular}{|c|c|c|c|c|c|}
\hline 13. & $\begin{array}{l}\text { Birkaç farklı şekilde cevaplar } \\
\text { sunan alıştırmalar yapılır. }\end{array}$ & $\begin{array}{c}1 \\
(\% 0.9)\end{array}$ & $\begin{array}{c}12 \\
(\% 11)\end{array}$ & $\begin{array}{c}31 \\
(\% 28.4)\end{array}$ & $\begin{array}{c}65 \\
(\% 59.6)\end{array}$ \\
\hline 14. & $\begin{array}{l}\text { Verilen metnin konusuna ya } \\
\text { da içeriğine yönelik } \\
\text { alıștırmalar yapılır. }\end{array}$ & $\begin{array}{c}1 \\
(\% 0.9)\end{array}$ & $\begin{array}{c}5 \\
(\% 4.6)\end{array}$ & $\begin{array}{c}31 \\
(\% 28.4)\end{array}$ & $\begin{array}{c}72 \\
(\% 66.1)\end{array}$ \\
\hline
\end{tabular}

Tab. 3: Plus+ Deutsch A1.1” Almanca Ders Kitabında Yer Alan Alı̧̧ırma Türlerinin Derslerde Uygulanma Durumu Yüzdelikleri

Tablo 3 incelendiğinde madde 2'de bulunan 'Üç ve daha fazla kişiden oluşan gruplarda çalışmalar yapılır” maddesinde \% 11.8'i hiç uygulanmıyor ve \% 38.8'i arada bir uygulanıyor sonuçları manidardır. Köksal ve Alibegovic'in (2016) yaptığ Slovenya'da yapılan üniversite düzeyindeki bir ders aynı şekilde Türkiye'deki üniversite öğrencilerine uygulandığında Türk öğrencilerin grup çalışmalarına daha az bireysel çalışmalara ise daha alışık olduğu görülmüştür. Tablo 3'e göre Almanca derslerinde en çok şu alıştırmalar her zaman uygulanmaktadır: Verilen metnin konusuna ya da içeriğine yönelik alıştırmalar (\% 66.1), konuşmaların-diyalogların ikişerli gruplar halinde okunduğu anlamaya yönelik alıştırmalar (\% 60.6), sınıfta soruların sorulduğu ve cevapların verildiği alıştırmalar (\% 59.6), birkaç farklı şekilde cevaplar sunan alıştırmalar (\% 59.6), örnek olarak verilen bir metne yönelik yazılı ve sözlü cevaplandırılacak alıştırmalar (\%56).

Araştırmanın ikinci alt problem cümlesi olan "Plus+ Deutsch A1.1" adlı Almanca ders kitabındaki alıştırma türlerinin derslerde uygulanma durumuna yönelik öğretmen görüşlerinden elde edilen bulgular bu bölümde yer almaktadır. Öğretmenlerin görüşleri bireysel görüşmelerde şu sorular ve yanıtlar alınmıştır:

a) Plus + Deutsch Almanca ders kitabında yer alan alıştırma türlerinin derslerde uygulanabilirliği hakkında ne düşünüyorsunuz?

Araştırmaya katılan öğretmenler bu ders kitabında yer alan alıştırma çeşitlerinin derslerde uygulanabilir olduğunu $(n=3)$, alıştırmalar derslerde uygulandığında öğrencinin ilgisinin arttığını $(n=1)$, alıştırmaların uygulanabilirlik anlamında dört beceriyi de kapsadığını ve temel seviyeye uygunluğu açısından yeterli olduğunu ifade etmişlerdir $(\mathrm{n}=2)$. Ayrıca bazen dilbilgisi konularından sonra alıştırmaların yetersiz gelebildiği de öğretmen görüşlerinde yer almaktadır. "Geçen seneki ders kitaplarına göre daha iyi olduğunu düşünüyorum, alıştırmaları güzel ve yeterli, sadece dilbilgisi konularından sonra alıştırmalar yetersiz kalıyor" (AÖ2). "Bu sene kitab1 içerik olarak hafiflettiler, alıştırmaları biraz daha uygulanabilir yaptılar. Böyle olunca öğrencilerin de ilgisini çekiyor. Şu anda büyük bir sıkıntı yok, alıştırmalar uygulanabiliyor” (AÖ1). "Uygulanabilirlik anlamında dört beceriyi de tamamen ölçme yönünde yeterli olduğunu düşünüyorum. Temel seviye olarak A1 başlangıç aşaması olarak alıştırmalar yeterli” (AÖ3). 
b) Plus+ Deutsch Almanca ders kitabındaki kolaylıkla uygulanabilen ya da uygulamada sıkıntılı sayılabilecek alıştırma türlerine ilişkin görüşleriniz nelerdir?

\begin{tabular}{|c|c|c|}
\hline Ana Temalar & Alt Temalar & $\mathbf{n}$ \\
\hline \multirow{5}{*}{ Kolay uygulanabilen alıştırmalar } & Yazma alanı bırakılan alıştırmalar & 1 \\
\hline & Kelime yerleştirme & 1 \\
\hline & Fiil çekimleri & 1 \\
\hline & Eşleştirmeler & 1 \\
\hline & $\begin{array}{l}\text { Basit cümlelerin tekrar ettirilebildiği } \\
\text { alıştırmalar }\end{array}$ & 1 \\
\hline \multirow{3}{*}{ Uygulamada zorluk çıkarabilen alıştırmalar } & Bazı dinleme alıştırmaları & 1 \\
\hline & Akran (ikili) grup oluşturma alıştırmaları & 2 \\
\hline & Diyalog oluşturma alıştırmaları & 1 \\
\hline
\end{tabular}

Tab. 4: Plus+Deutsch Almanca Ders Kitabındaki Kolaylıkla Uygulanabilen ya da Uygulamada Sıkıntılı Sayılabilecek Alıştırma Türleri Hakkındaki Öğretmen Görüşlerine İlişkin Oluşturulan Temalar

Tablo 4'de görüldügü üzere öğretmenler öğrenciye yazma alanı bırakılan alıştırmaları, kelime yerleştirmelerinin, fiil çekimlerinin, eşleştirmelerin yapıldı ̆̆ı alıştırmaları ve basit cümlelerin tekrar ettirilebildiği alıştırmaları derslerde kolaylıkla uygulayabildiklerini ifade etmişlerdir. Ayrıca öğretmenler akran grup oluşturma ile diyalog oluşturma alıştırmalarını ise sınıfların kalabalık olmasından dolayı derslerde uygulamakta sorun yaşadıklarını belirtmişlerdir. Öğretmenlerin konuya ilişkin bazı ifadeleri şöyledir: "Karışık kelime verip yerleştirme ya da fiil çekimleri, eşleştirme etkinliklerini kolay uygulayabiliyoruz" (AÖ1). "Partner oluşturup sırayla alıştırma yaptırma biraz zorluyor. Bir de karş1lıklı diyalog oluşturmada öğrenciler belli bir kalıpların dışına çıkamıyorlar ya da kitaptaki örnek yetersiz kalıyor o an” (AÖ2).

c) Plus+ Deutsch Almanca ders kitabındaki alıştırma türlerinin derslerde ardıl şekilde birbirini izleyerek uygulanması konusunda neler söyleyebilirsiniz?

Öğretmenler tarafından ders kitabında art arda yer alan alıştırmaların birbiriyle bağlantılı olduğu $(n=1)$, bu nedenle öğrencilerin tekrar etmesini mümkün kıldığı $(n=1)$, ama arada bir gerçekleştirilemeyen alıştırmalar olsa da çoğu alıştırmaların gerçekleştirildiği $(n=1)$, gerekli görülmeyen alıştırmaların atlanabildiği belirtilmiştir $(n=1)$. Alıştırmaların sırayla verilmesinin düzen oluşturduğu da öğretmen görüşleri arasındadır $(\mathrm{n}=1)$. Bu temalara ilişkin bazı öğretmen ifadeleri şu şekildedir: "Alıştırmaları yapıp tekrar ardı ardına alıştırma yapmak öğrenciler için tekrar gibi oluyor. Ödev olarak verebiliyordum öyle olduğunda alıştırmaları" (AÖ1). "Mutlaka atladıklarımız oluyor. Bazıları mesela o konuyla ilgili çok basit çok yetersiz veya 
yapılmasa da hiçbir şey kaybettirmeyecek alıştırmalar var, onları es geçiyoruz. Her zaman o ardışık sırayı takip ediyoruz diyemem" (AÖ2).

d) Sizce Plus+ Deutsch Almanca ders kitabinda yer alan ve derslerde uygulanan alıştırma türleri öğrencilerin iletişimsel edinç kazanmasını nasil etkilemektedir?

\begin{tabular}{|c|c|}
\hline Temalar & n \\
\hline Temel seviye için yeterli & 2 \\
\hline Konuşma ve yazmaya yönelik ihtiyaç oluşma & 1 \\
\hline Dinleme metinleri & 1 \\
\hline İletişim olarak konuşma & 1 \\
\hline Olumlu yönde etkileme & 1 \\
\hline Almanca soru sormaya yönelme & 1 \\
\hline Alıştırmaları devam ettirme & 1 \\
\hline Kelimeleri kullanma & 1 \\
\hline Öğrencileri teşvik etme & 1 \\
\hline
\end{tabular}

Tab. 5: Plus+ Deutsch Almanca Ders Kitabında Yer Alan ve Derslerde Uygulanan Alıştırma Türlerinin Öğrencilerin İletişimsel Edinç Kazanmasını Nasıl Etkilediği Konusundaki

Öğretmen Görüşlerine İlişkin Oluşturulan Temalar

Araştırmaya katılan öğretmenler Plus + Deutsch Almanca ders kitabında yer alan ve derslerde uygulanan alıştırma türlerinin öğrencilerin iletişimsel edinç kazanması bağlamında temel seviyeyi oluşturmak için yeterli olduğunu $(n=2)$, ancak konuşma ve yazma becerisine biraz daha ağırlık verilmesi gerektiğini ifade etmişlerdir $(n=1)$. Görüşmeye katılan öğretmen iletişim olarak konuşma becerisi düşünülürse alıştırmaların ancak dönem sonuna doğru öğrencilere katkı sağladığını $(n=1)$ ve dinleme metinlerinin iletişimsel edinç bağlamında faydalı olduğunu ifade etmiştir $(n=1)$. Öğretmen iletişim kurarken alıştırmaları örnek almakta ve Almanca soru sormaya, öğrendikleri kelimeleri kullanmaya yönelmektedir. Uygulanan alıştırmalar öğrencileri yapamadıkları alıştırmaları öğretmenlerine sormak için yönlendirmekte yani onları öğrenmeye ve iletişime teşvik etmektedir. Öğretmenler bu görüşlerini “Aslında 2 saatlik dersimiz olduğu için alıştırmalar temel seviyeyi oluşturmak için yeterli, ancak daha çok konuşma ve yazmaya ihtiyaç var" (AÖ1). "İletişimsel anlamda da olumlu yönde etkiliyor. Mesela ufak tefek sorularda bile Almanca sormaya, iletişim kurarken daha çok böyle hemen o alıştırmadaki devam etmeye çalışıyorlar, Almanca soru sormaya çalışıyorlar. Öğrendiği birkaç kelimeyi hemen kullanmaya çalışıyorlar" (AÖ2). "Ben programa göre ilerliyorum, alıştırmaları da yapıyoruz çok ileri giden öğrencilerim de oluyor yapamayan da, o zaman beraber de iletişim kurmaya çalışıyoruz" (AÖ3) şeklindeki bazı ifadeleriyle konu ile ilgili düşüncelerini dile getirmişlerdir.

Araştırmanın üçüncü alt problem cümlesi olan "Plus+ Deutsch A1.1" adlı Almanca ders kitabındaki alıştırma türlerinin derslerde uygulanma durumuna yönelik 
öğrenci görüşlerinden elde edilen bulgular bu bölümde yer almaktadır. Öğrencilerle yapılan bireysel görüşmelerde öğrencilere aşağıdaki sorular yöneltilmiştir.

a) Sizce Almanca ders kitabında yer alan bütün alıştırmaların derslerde uygulanma durumu nasıldır?

\begin{tabular}{|c|c|c|}
\hline Ana Temalar & Alt Temalar & $\mathbf{n}$ \\
\hline \multirow{5}{*}{ Uygulanma } & Çoğunlukla uygulanıyor & 4 \\
\hline & Uygulamaya elverişli alıştırmalar uygulanıyor & 2 \\
\hline & Almanca-Türkçe çeviri yapılıyor & 1 \\
\hline & Ödev veriliyor & 1 \\
\hline & Sürekli uygulanıyor & 1 \\
\hline \multirow{2}{*}{ Uygulanmama } & Uygulamaya elverişli olmayan alıştırmalar uygulanmıyor & 2 \\
\hline & Çok az da olsa alıștırmaların uygulanmadığı oluyor. & 3 \\
\hline
\end{tabular}

Tab. 6: Almanca Ders Kitabında Yer Alan Bütün Alıştırmaların Derslerde Uygulanma Durumunun Nasıl Olduğu Konusundaki Öğrenci Görüşlerine İlişkin Oluşturulan Temalar

Tablo 6'daki ana temalar ve alt temalarda da görüldüğü gibi öğrenci görüşlerine göre işledikleri ders kitabında yer alan bütün alıştırmalar derslerde çoğunlukla uygulanmakta ve uygulanmayan çok az alıştırma bulunmaktadır. Alıştırmalar uygulanırken Almancadan Türkçeye çeviri yapılmaktadır. Ayrıca alıştırmaların uygulanması için ders süresi yeterli olmadığında alıştırmalar ödev aracılığıyla uygulanmaktadır. Alıştırmaların uygulanma durumuna ilişkin bazı öğrenci ifadeleri şu şekildedir: "Genelde hepsini uyguluyoruz" (Ö2). "Bazıları uygulanabilecek şekilde oluyor, bazıları ise olmuyor, daha çok yapabildiklerimizi uyguluyoruz" (Ö1). "Mesela hocamız Almanca verileri Türkçeye çeviriyor. Örneklemeler yapıyor bizim için. Yani alıştırmalar yetiyor, artıyor bile” (Ö5). "Sürekli uygulanıyor ders kitabındaki etkinlikler, alıştırma kitabında vaktimiz kalmadığ zamanlar ödevler veriliyor" (Ö5). "Bazı uygulanamayacak olanları uygulamıyoruz" (Ö4). "Uygulamadığımız çok olmuyor" (Ö3).

b) Almanca ders kitabındaki alıştırmaların derslerde uygulanmasını nasıl değerlendiriyorsunuz?

\begin{tabular}{|c|c|}
\hline Temalar & $\mathbf{n}$ \\
\hline Alıştırmalar çoğunlukla sırasıyla uygulanıyor & 5 \\
\hline Alıştırmalar bazen atlanabiliyor & 5 \\
\hline Alıştırmalar daima sırasıyla uygulanıyor & 1 \\
\hline Öğrenilenlerin pekiştirilmesini sağlıyor & 1 \\
\hline
\end{tabular}

Tab. 7: Öğrencilerin Almanca Ders Kitabındaki Alıştırmaların Derslerde Uygulanmasını Nasıl Değerlendiriyorsunuz Konusundaki Öğrenci Görüşlerine İlişkin Oluşturulan Temalar 
Öğrenci görüşlerine göre Almanca ders kitabındaki alıştırmalar derslerde çoğunlukla sırasıyla uygulanırken bazı durumlarda bir alıştırma uygulandıktan sonra sıradaki alıştırmalar yerine diğer alıştırmalar uygulanmaktadır. Alıştırmaların ardıl bir şekilde uygulanmasına ilişkin bazı öğrenci ifadeleri aşağıda örnek olarak verilmiştir: "Derslerde uygulayabildiklerimizi uyguluyoruz. İyi oluyor yani öğrendiklerimizi pekiştirmemiz açısından alıştırma yapmış oluyoruz. Bazen atlayıp geçebiliyoruz. Bunu şu an yapamayacağız diyoruz ya da hani buna gerek yok deyip geçtiğimiz oluyor bazen" (Ö1)."Sıradakine geçiyoruz, atlanan olmuyor bizde. Bazen o konuyu başka bir zaman işleyeceksek atlıyoruz, çok az” (Ö2). "Arada atladığımız sorular oluyor mesela 2'yi atlayıp 3'e geçtiğimiz oluyor" (Ö6).

c) Almanca ders kitabında bulunan ve derslerinizde uygulanan alıştırmalar iletişim kurmanızı nasıl etkiliyor?

\begin{tabular}{|l|c|c|}
\hline \multirow{2}{*}{ Ana Temalar } & Alt Temalar & n \\
\hline \multirow{4}{*}{ Olumlu etkileme } & Diyalog alıştırmaları & 1 \\
\cline { 2 - 3 } & Telaffuzu kolaylaştırma & 2 \\
\cline { 2 - 3 } & Sorular aracılığıyla iletişim kurma & 1 \\
\cline { 2 - 3 } & Konuşma imkanı sunma & 1 \\
\cline { 2 - 3 } & Tartışma ortamı sağlama & 1 \\
\cline { 2 - 3 } & Fikirlerin ifade edilmesine imkan sunma & 1 \\
\hline
\end{tabular}

Tab. 8: Almanca Ders Kitabında Bulunan ve Derslerde Uygulanan Alıştırmaların Öğrencilerin İletişiı Kurmasını Nasıl Etkilediği Konusundaki Öğrenci Görüşlerine İlişkin Oluşturulan Temalar

Öğrenci görüşlerine göre Almanca derslerinde uygulanan alıştırmalar öğrencilerin iletişim kurmalarını olumlu yönde etkilemektedir. Diyalog alıştırmaları ile öğretmen ve öğrenciler arasındaki Almanca sorular sorulması öğrencilere iletişimsel bağlamda katkı sağlamaktadır. Ayrıca alıştırmalar öğrencilerin telaffuzlarını kolaylaştırmakta, onlara konuşma, tartışma ve fikirlerini ifade etme ortamı sunmaktadır. Bu konuda bazı öğrenciler "İyi etkileri oluyor. Çünkü alıştırmaların arasında arkadaşlarımızla konuşma gibi diyalog kurma ya da defterde kendimiz cümle kurma, diyalog kurma olarak Almanca olarak konuşmamızı geliştiriyor" (Ö1). "Bir örnek cümle verdiğinde Hoca hepimize teker teker sorup Almanca sorular sorup sürekli bütün öğrencilerle bunu yapıyoruz" (Ö3). "Mesela hiç konuşmayan kişi de konuşabiliyor, tartışma konusu ortamı oluyor, olumlu yönde, çoğu kişi fikrini söylüyor” (Ö5). "Almancayı daha iyi telaffuz etmemizi etkiliyor" (Ö4) ifadeleri ile görüşlerini yansıtmışlardır.

\section{Sonuçlar ve Öneriler}

Öncelikle çalışmanın kuramsal bölümünde bilişsel anlamda Bloom'un yenilenen bilişsel süreç basamakları, iletişimsel anlamda da Funk vd.'nin (2014) belirlediği alıştırma türleri temel alınarak "Plus+ Deutsch A1.1" adlı Almanca ders kitabından örnekler 
verilmiştir. Bu bağlamda "Plus+ Deutsch A1.1" Almanca ders kitabının öğrencilerin hem zihinsel gelişimine hem de iletişimsel edinç kazanmasına yönelik alıştırma türlerinin olduğu tespit edilmiştir.

Araştırmanın birinci alt problemi olan "Plus+ Deutsch A1.1" Almanca ders kitabında yer alan alıştırma türlerinin derslerdeki uygulanması hakkında öğrencilere uygulanan anket sonuçlarına göre ders kitabındaki farklı türdeki alıştırmalardan "üç ve daha fazla kişiden oluşan gruplarda" maddesinde yapılan çalışmalar derslerde arada bir uygulanmakta, diğer alıştırma türleri genellikle uygulanmaktadır. Uygulanan bu alıştırmaların başında ise "Verilen metnin konusuna ya da içeriğine yönelik alıştırmalar", "Konuşmaların-diyalogların ikişerli gruplar halinde okunduğu alıştırmalar", "Sınıfta soruların sorulduğu ve cevapların verildiği alıştırmalar" ile "Birkaç farklı şekilde cevaplar sunan alıştırmalar" gelmektedir. Dolayısıyla bu bulgu, içerik odaklı alıştırmaların, yarı açık uçlu alıştırmaların ve iletişimsel edinç geliştirmeye yönelik alıştırmaların derslerde daha fazla uygulandığı şeklinde yorumlanabilir.

Araştırmanın ikinci alt problemi olan "Plus+ Deutsch A1.1" Almanca ders kitabındaki alıştırma türlerinin derslerde uygulanma durumuna yönelik öğretmen görüşlerine göre ders kitabındaki alıştırma türleri çoğunlukla derslerde uygulanabilir niteliktedir. Alıştırmalar derslerde uygulandığında öğrencinin de ilgisi artmaktadır. Alıştırmalar uygulanabilirlik anlamında dört beceriyi de kapsamakta ve temel seviyeye uygunluğu açısından yeterli olmaktadır. Ancak bazen dilbilgisi konularından sonra alıştırmalar yetersiz kalabilmektedir. Öğrenciye yazma alanı bırakılan alıştırmalar, kelime yerleştirmelerinin, fiil çekimlerinin, eşleştirmelerin yapıldığı alıştırmalar ve basit cümlelerin tekrar ettirilebildiği alıştırmalar öğretmenler tarafından derslerde kolaylıkla uygulanabilmektedir. Bazı dinleme alıştırmaları, akran (ikili) grup ve diyalog oluşturma alıştırmaları ise uygulamada sorun yaratmaktadır. Alıştırma türleri derslerde büyük oranda ders kitabındaki gibi ardıl bir şekilde uygulanmaktadır. Çünkü öğretmenler ders kitabında art arda yer alan alıştırmaların birbiriyle bağlantılı olduğu, bir düzen oluşturduğu ve bu nedenle öğrencilerin tekrar etmesini mümkün kıldığı görüşündedirler. Ancak çok az da olsa bir alıştırma uygulandıktan sonra sıradaki alıştırma(lar) yerine daha sonraki alıştırmaya, ya da alıştırmalara, geçildiği durumlar da söz konusu olmaktadır.

Araştırmanın üçüncü alt problemi olan "Plus+ Deutsch A1.1" adlı Almanca ders kitabındaki alıştırma türlerinin derslerde uygulanma durumuna yönelik öğrenci görüşlerine göre ise Plus+ Deutsch Almanca ders kitabında yer alan uygulanmaya elverişli bütün alıştırmalar derslerde çoğunlukla uygulanmaktadır. Uygulanmaya elverişli olmayan alıştırmalar ise derslerde uygulanamamaktadır ve bu az da olsa yaşanan bir durumdur. Alıştırmalar çoğunlukla kitaptaki gibi ardıl sırayla derslerde uygulanmaktadır. $\mathrm{Bu}$ sıranın takip edilemediği durumlar ise oldukça azdır. Alıştırmaların derslerde uygulanması öğrencilerin telaffuzlarını kolaylaştırmakta, onlara konuşma, tartışma ve fikirlerini ifade etme ortamı sunmaktadır. Bu alıştırmalar öğrencilerin iletişim edinç kazanmasını desteklemektedir. $\mathrm{Bu}$ bağlamda diyalog alıştırmaları ile öğretmen ve öğrenciler arasındaki Almanca sorular sorulması öğrencilere iletişimsel bağlamda katkı sağlamaktadır. 
Araştırma sonuçları bütüncül olarak değerlendirildiğinde öğrencilerin bilişsel, sosyal ve iletişimsel gelişimini destekleyen "Plus+ Deutsch A1.1" Almanca ders kitabındaki alıştırma türlerinin çoğunlukla derslerde uygulandığı ve bu alıştırmaların uygulanırken genellikle kitaptaki gibi ardıl şekilde belirli sıra takip edildiği sonucuna varılmaktadır. Çok nadir olarak bazı alıştırmaların uygulanmadan geçilmesi ise alıştırmaların uygulamaya elverişli olmamasına bağlıdır. Bu durumda bazı alıştırmaların o an derslerde uygulanabilir nitelikte olmamasindan ya da sinıf mevcudunun fazla olmasından dolayı atlandığı yorumu yapılabilir. Araştırmaya konu olan ders kitabındaki alıştırma türlerinin ve bunların derslerde uygulanmasının öğrencilere iletişim edinç kazandırdığ 1 sonucuna da ulaşılmaktadır. Araştırma sonuçlara dayanarak Almanca derslerinin Ortaöğretim Almanca müfredatında amaçlandığ gibi öğrencilerin Almanca dil yeterliliklerinin dört temel beceri doğrultusunda geliştirilmesine ve yaşam boyu öğrencilerin bireysel ihtiyaçlarına göre şekillendireceği iletişim edincinin öğrencilere kazandırılmasına hizmet ettiği söylenebilir. Araştırmaya daha fazla katılımcı dâhil edilerek araştırma genişletilebilir, "Plus+ Deutsch A1.1" Almanca ders kitabı dışındaki ders kitaplarında yer alan alıştırma türleri iletişimsel edinç bağlamında değerlendirilebilir ve alıştırmaların ders işleyiş sırasında neden atlandığı araştırılabilir.

\section{Kaynakça}

Açıkgenç, Alparslan/ Köse, Mehmet Ruhi/ Günel, M/ Demirkol, Murat (2011): MEB 21. Yüzyıl Öğrenci Profili, T.C. Millî Eğitim Bakanlığı Eğitimi Araştırma ve Geliştirme Dairesi Başkanlığı, Ankara. https://www.meb.gov.tr/earged/earged/21.\%20yy_og_pro.pdf (son erişim tarihi: 02.03.2021).

Akar, Hanife (2016): Durum Çalışması, içinde: Saban, Ahmet ve Ersoy, Ali (Ed.) Eğitimde Nitel Araştırma Desenleri (pp. 111-149), Ankara: An1.

Akpınar Dellal, Nevide/ Çınar, Servet (2011): Yabancı Dil Eğitiminde İletişimsel Yararcı Yaklaşım, Öğretmen Rolleri, Davranışları ve Sınıf İçi İletişim, Dil Dergisi, 154, 21-36. https://dergipark.org.tr/tr/pub/dilder/issue/47687 (son erişim tarihi: 02.03.2021).

Aktaş, Tahsin (2005): Yabancı Dil Öğretiminde İletişimsel Yeti. Journal of Language and Linguistic Studies, 1(1), 89-100. https://www.jlls.org/index.php/jlls/article/view/9/10. (son erişim tarihi: 02.03.2021).

Anderson, Lorin W./ Krathwohl, David R./ Airasian, Peter W./ Cruikshank, Kathleen A./ Mayer, Richard E./ Raths, James/ Wittrock, Merlin C. (Eds.) (2001): A Taxonomy for Learning, Teaching, and Assessing: A Revision of Bloom's Taxonomy of Educational Objectives. New York: Addison Wesley Longman.

Arslan, Mehmet (2007): Eğitimde Yapılandırmacı Yaklaşımlar. Ankara Üniversitesi Ĕ̆itim Bilimleri Fakültesi Dergisi, 40(1). https://dergipark.org.tr/tr/download/article-file/509082 (son erişim tarihi: 02.03.2021).

Baliuk, Natallia/ Buda, Filippa/ Rösler, Dietmar/ Würffel, Nicola (2018): Einführung Kommunikativer Ansatz. içinde: DAAD (Hrsg.), Dhoch3-Studienmodule Deutsch als Fremdsprache.moodle.daad.de. https://www.ucg.ac.me/skladiste/blog_4856/objava_54750/fajlovi/KA_Text.pdf (son erişim tarihi: 02.03.2012). 
Büyüköztürk, Şener/ Kılıç Çakmak, Ebru/ Akgün, Özcan Erkan/ Karadeniz, Şirin/ Demirel Funda (2019): Eğitimde Bilimsel Araştırma Yöntemleri. Ankara: Pegem Akademi.

Doyé, Peter (1988): Typologie der Testaufgaben für den Unterricht Deutsch als Fremdsprache. Langenscheidt: Berlin und München.

Ekinci, Necla (2015): İşbirliğine Dayalı Öğrenme, içinde: Özcan, Demirel (Ed.) Eğitimde Yeni Yönelimler (pp. 93-109), Ankara: Pegem Akademi.

Er, Sühendan/ Aral, Neriman (2008): Yapılandırmacı Yaklaşıma Göre Düzenlenmiş Sınıflarda Öğretmenin Rolü. Ekev Akademi Dergisi, 12(35), 391-396.

Funk, Hermann/ Kuhn, Christina/ Skiba, Dirk/ Spaniel-Weise, Dorothea/ Wicke, Rainer E. (2014): Aufgaben, Übungen, Interaktion. Goethe-Institut/Klett: Stuttgart.

Güneş, Firdevs (2011): Dil Öğretim Yaklaşımları ve Türkçe Öğretimindeki Uygulamalar. Mustafa Kemal Üniversitesi Sosyal Bilimler Enstitüsü Dergisi, 8(15), 123-148. https://pegem.net/dosyalar/dokuman/122219-2011062815530-06gunes.pdf (son erişim tarihi: 02.03.2021).

Häussermann, Ulrich/ Piepho, Hans-Eberhard (1996): Aufgabenhandbuch Deutsch als Fremdsprache. Abriß einer Aufgaben- und Übungstypologie. Iudicium Verlag: München.

Kaleli Yılmaz, Gül (2015): Durum çalışması, içinde: Mustafa, Metin (Ed.) Kuramdan Uygulamaya Eğitimde Bilimsel Araştırma Yöntemleri (261-285), Ankara: Pegem Akademi.

Köksal, Handan/ Alibegoviç, Elma (2016): Kontrastiver Vergleich zwischen einem DaFUnterrichtsverlauf in der Türkei und in Slowenien. Zeitschrift für die Welt der Türken, 8(2), 105122. http://www.dieweltdertuerken.org/index.php/ZfWT/article/view/845 (son erişim tarihi: 18.06.2021).

Lingyan, Qian (2016): Sprachenlernen im Tandem. Eine empirische Untersuchung über den Lernprozess im chinesisch-deutschen Tandem, Tübingen: Narr Francke Attempto.

Neuner, Gerhard/ Krüger, Michael/ Grewer, Ulrich (1981): Übungstypologie zum kommunikativen Deutschunterricht. Langenscheidt: Berlin und München.

Ortaöğretim Almanca Dersi (Hazırlık 9, 10, 11. ve 12. Sınıflar) Öğretim Programı (2018): http://mufredat.meb.gov.tr/ProgramDetay.aspx?PID=333 (son erişim tarihi 02.03.2021).

Özbal, Bayram/ Genç, Ayten (2019): "Yabancı dil olarak Türkçe" ders kitaplarında alıştırma yönergelerinin değerlendirilmesi. Hacettepe Üniversitesi Türkiyat Araştırmalarl Dergisi, (31), 123-146. https://dergipark.org.tr/tr/pub/turkiyat/issue/51200/550884 (son erişim tarihi: 02.03.2021).

Schwerdtfeger, Inge C./ Meese, Herrad (2001): Gruppenarbeit und innere Differenzierung. Fernstudieneinheit 29. Berlin: Langenscheidt.

Sönmez, Veysel (2017). Öğretim ilke ve yöntemleri. Ankara: Anı Yayıncılık.

Thonhauser, Ingo (2010): Was ist neu an den Aufgaben im aufgabenorientierten Fremdsprachenunterricht? Einige Überlegungen und Beobachtungen. Babylonia, 3 (10), 8-16. http://babylonia.ch/fileadmin/user_upload/documents/2010-3/Baby2010_3thonhauser2.pdf (son erişim tarihi: 02.03.2021).

Trim, John/ North, Brian/ Caste, Daniel (2001): Gemeinsamer europäischer Referenzrahmen für Sprachen: lernen, lehren, beurteilen. Berlin München: Langenscheidt. http://student.unifr.ch/pluriling/assets/files/Referenzrahmen2001.pdf (son erişim tarihi: 02.03.2021). 
Weskamp, Rolf (2004): Aufgaben im fremdsprachlichen Unterricht, Praxis Fremdsprachenunterricht, 3 , 162-170. http://arbeitsplattform.bildung.hessen.de/fach/2/Info/4_02_WeskampAufgabenin_FS.pdf (son erişim tarihi: 02.03.2021).

Yıldırım, Ali/ Şimşek, Hasan (2018): Sosyal Bilimlerde Nitel Araştırma Yöntemleri. Ankara: Seçkin.

Yılmaz Yiğit, Derya (2019): Plus+ Deutsch Deutsch als Fremdsprache für Gymnasien Schülerbuch A1.1. Ankara: Koza Yayın.

Zengin, Ramazan (1995): Yabancı dil olarak Türkçe öğretiminde alıştırmalar, Yayımlanmamış Yüksek Lisans Tezi, İstanbul Üniversitesi Sosyal Bilimler Enstitüsü, İstanbul. 